\title{
Phylogenetic Analysis of the Antibiotic Resistance Genes in Salmonella Species in silico
}

\author{
Nusrat Nahar* and Ridwan Bin Rashid
}

Computational Chemistry and Bioinformatics Laboratory, Department of Pharmacy, State University of Bangladesh, Dhaka, Bangladesh

\begin{abstract}
Antibiotic resistance is an emerging problem in both developed and developing countries. It has been responsible for 700,000 deaths worldwide. Some genotypes of bacteria are sensitive to certain antibiotics than others. Hence by conducting phylogenetic analysis of bacteria and detecting the presence of resistance genes in each genotype, we can select the antibiotic that would be most effective for the bacteria in that certain genotype. A total of fortyfive Salmonella species were investigated for the presence of antibiotic resistance genes through in silico PCR (polymerase chain reaction) amplification and PFGE (pulsed-field gel electrophoresis) analysis was conducted to assess the phylogenetic relationship. Total twenty-eight antibiotic resistance genes were selected for screening the isolates and seventeen antibiotic resistance genes among the Salmonella strains were found. Almost all the isolates $(n=43)$ exhibited PCR amplification product for gyrA genes while fluoroquinolone resistance gyrB $(66.67 \%)$, parC $(68.89 \%)$ and parE (15.56\%) genes were also present. About $15.56 \%$ and $11.11 \%$ isolates were found to harbor adenylyltransferase gene, aadA1 and aadA2, respectively while phosphotransferase gene was detected in only one isolate. Two isolates expressed both chloramphenicol acetyltransferase genes, cat1 and cat2. Three isolates $(6.67 \%)$ harbored chloramphenicol resistance gene $\mathrm{cmlA}$ gene while two isolates $(4.44 \%)$ expressed florfenicol resistance gene, floR. Tetracycline resistance gene, tetA was more prevalent $(8.89 \%)$ than tetG genes $(2.22 \%)$. Salmonella harbored all three sulfonamide resistance genes while sulll was more prevalent (17.78\%). Genotype 2 contained fifteen antibiotic resistance genes while genotype 3 contained only one antibiotic resistance genes. These investigations used a computer aided approach to genotype isolates and assess the difference in antibiotic resistance profile of Salmonella species based on genotype. This data helps to predict antibiotic resistance genes that might be present for an isolate of known genotype and select antibiotic for the treatment of Salmonella infections based on their phylogenetic group.
\end{abstract}

Keywords: Salmonella; In silico; Antibiotic resistance genes; Polymerase chain reaction; Pulsed-field gel electrophoresis; Genotype

\section{Introduction}

Zoonotic bacterium Salmonella colonizes on the intestinal tract. Humans and animals are affected by many diseases caused by Salmonella such as acute gastroenteritis, bacteremia and many other extraintestinal localized infections. So, rapid identification of Salmonella is needed to prevent the spread of the diseases [1]. Poultry products are the potential source of Salmonella infections $[2,3]$ that cause significant economic loss in the poultry industry $[1,4]$.

Animals that contribute to food production are treated with antimicrobials for therapeutics or production purposes. These antimicrobials improved animal health and their growth rate or feed conservation was reported by one study [5]. This overuse of antimicrobials also contributed to the development of multidrugresistant bacteria including zoonotic pathogen Salmonella [3]. Multidrug-resistant (MDR) Salmonella has been increased worldwide due to overuse of antibiotics in humans and animal's infections. One study documented that seafood, chickens and fishes were considered as the source of Salmonella infections [6]. Another investigation screened Salmonella collected from food handler and animal isolates that showed same RAPD fingerprinting patterns. So, the animal was the root of the source for food handler infections as food handlers used these collected samples [7].

Deaths due to drug-resistant infections are estimated to increase from 700,000 to 10 million annually by 2050 , and the financial burden because of this might be as high as US $\$ 100$ trillion worldwide [8]. In developing countries, antimicrobials are used inappropriately in farming practices and this is contributed to the development of multidrug-resistant bacteria [9]. Non typhoidal Salmonella enterica was responsible for 56,969 deaths globally in 2010 [10]. Typhoidal Salmonella was responsible for 210,000 deaths worldwide in 2000 [11]. In Nigeria, multidrug-resistant (MDG) Salmonella is of important concern as it was responsible for bacteremia in children [12].

Recently one group found that third-generation fluoroquinolones were effective for the treatment of adult patients [13]. World Health Organization listed fluoroquinolones as an important antibiotic and its use for the treatment of children was reported by one group [14]. However, a study found a Salmonella serotype from a human source that showed a reduction in fluoroquinolone susceptibility [15]. One study found that a single mutation in DNA topoisomerase gene was responsible for the development of fluoroquinolone resistant Salmonella enterica [16]. Presence of gyrA mutation is an indicator of fluoroquinolone resistance gene and hence fluoroquinolones cannot be prescribed for treating the infection [17]. Mutations in DNA gyrase, gyrA genes were usually restricted to clinical human and veterinary samples [16,18-20].

*Corresponding author: Nusrat Nahar, Computational Chemistry and Bioinformatics Laboratory, Department of Pharmacy, State University of Bangladesh, Dhaka, Bangladesh, Tel: 09613782338; E-mail: nusratnahar17@gmail.com

Received December 26, 2017; Accepted January 15, 2018; Published January 22, 2018

Citation: Nahar N, Rashid RB (2018) Phylogenetic Analysis of the Antibiotic Resistance Genes in Salmonella Species in silico. J Bioanal Biomed 10: 1-12. doi:10.4172/1948 593X.1000198

Copyright: @ 2018 Nahar N, et al. This is an open-access article distributed under the terms of the Creative Commons Attribution License, which permits unrestricted use, distribution, and reproduction in any medium, provided the original author and source are credited. 
One study reported that chloramphenicol acetyltransferases (CAT), a plasmid-borne enzyme, was responsible for chloramphenicol resistance [21]. Another study documented nonenzymatic chloramphenicol resistance gene, $c m l A$, also conferred chloramphenicol resistance in Salmonella species [22]. Salmonella was also seen to harbour florfenicol resistance gene and it also showed cross-resistance to chloramphenicol [23].

In Iran, poultry originated Salmonella developed tetracycline resistance was reported by several authors [1,24-26]. Several reports found that tet $A$ was the most common tetracycline resistance gene found in poultry $[3,4,27]$. One study reported that tet $A$ and tet $B$ genes both were present in Salmonella collected from human samples [28]. Another group found tetD resistance gene in Salmonella [29]. Other studies found tetracycline resistant Salmonella typhimurium that harbored tet $G$ gene [30,31].

The sulI and sulII genes, encoding different forms of dihydropteroate synthase, are responsible for sulfonamide resistance [32]. Several studies documented that the sulI gene was linked to other resistance genes in class 1 integrons, while sulII gene was located on small nonconjugative plasmids [33] or large transmissible multi resistance plasmids [32]. Another study found sulfonamide resistance gene due to sulIII [34].

Salmonella usually develops their resistance mechanism by an enzymatic modification of the target compounds while other bacteria uses active efflux pump or enzymatic modification of $16 \mathrm{~S}$ rRNA subunit to develop their resistance mechanism [35]. For strains isolated in USA, acetyltransferases, phosphotransferases, and nucleotidyltransferases genes modified and inactivated the aminoglycoside antibiotics and conferred their resistance [36,37].

The present study investigated the resistance genes profile of fortyfive Salmonella species through in silico PCR amplification to determine the MDR gene profile and also identified the distribution pattern of the resistance genes within the genotypes by in silico PFGE analysis.

\section{Materials and Methods}

\section{Strains used in the study}

Strains used in the study are summarized in Table 1.

\section{Primers used in the study}

Primers used for detection of antibiotic resistance genes are summarized in Table 2 [38].

\section{PCR amplification}

In silico PCR amplification was performed on an online software http://insilico.ehu.eus/PCR/ [39,40] and resulting PCR product is computed automatically with desired band size of a specific gene [40].

\section{PFGE digestion}

PFGE digestion and construction of the dendrogram was done in the website http://insilico.ehu.es/digest/. The Xbal restriction enzyme was used that recognized the restriction sequence $[39,40]$.

\section{Results and Discussion}

\section{Genetic diversity of studied isolates}

Genetic diversity of Salmonella species is determined by pulsedfield gel electrophoresis (PFGE) analysis. The Xbal was chosen as a restriction enzyme that recognizes T'CTAG_A sequence and different banding patterns were observed upon gel electrophoresis. Dendrogram was constructed in the website (Figure 1). This in silico PFGE analysis divided 45 isolates into five genotypes at $80 \%$ cutoff value.

\section{Genotypic distribution of aminoglycosides resistance genes}

The gene products of aadA1 and aadA2 confers resistance to streptomycin and spectinomycin. The aadA1 gene was present in $15.56 \%(n=7)$ of the isolates and gave 497 bp gene product (Figure 2). The aadA2 gene was detected in $11.11 \%(\mathrm{n}=5)$ of the isolates with 470 bp gene product (Figure 3 ). The $a a d B$ gene cassette confers resistance to tobramycin, gentamicin and kanamycin [41]. The gene aadD confers resistance to kanamycin and neomycin [42] as well as tobramycin [43]. The primer for $a a d B$ and $a a d D$ genes [38] didn't give any amplicon in any of the isolates (not shown). The aph(3)-IIa specifies resistance to neomycin, ribostamycin, butirosin, paromomycin and kanamycin. One isolate was found to harbour phosphotransferase gene, aph (3')II $a$ with $582 \mathrm{bp}$ gene product (Figure 4). The aac(3)IIa gene mediates alteration of dibekacin, kanamycin, gentamicin, netimicin, tobramycin [37]. The primer of aac(3)IIa gene (Ma et la., 2007) [38] didn't give any amplicon. One study reported that phosphotransferase gene aph(3)II a genes were detected in $10(1.4 \%)$ isolates while $57 \%(\mathrm{n}=8)$ isolates had the acetyltransferase gene aac(3)IIa [13]. Based on our data, treatment of Salmonella infection is going to have a better prognosis if tobramycin, gentamicin, kanamycin, neomycin, ribostamycin, butirosin, paromomycin are used instead of other aminoglycosides such as streptomycin and spectinomycin.

Genotype 1 contained all three aminoglycoside positive genes while genotype 2 and 3 contained adenylyltransferase genes aadA1 and aadA2. About $22.22 \%$ isolates present in genotype 1 carried aadA1 gene while $11.11 \%$ isolates present in genotype 1 carried both aadA2 and $a p h\left(3^{\prime}\right)$-IIa genes. Phosphotransferase gene $a p h\left(3^{\prime}\right)-I I a$ was present in only genotype 1 . Genotype 3 contained no aminoglycosides or chloramphenicol resistance genes. About $11.76 \%$ and $17.65 \%$ isolates present in genotype 2 carried aadA1 and aadA2 genes while aadA1 was encountered in higher frequency (27.27\%) in genotype 5 as compared to aad $A 2$ genes $(9.09 \%)$. Isolates belonging to genotype 3,4 are unlikely to be resistant to streptomycin and spectinomycin and infections caused these genotype can be tackled with these antibiotics. All of the isolates are sensitive to dibekacin, gentamicin, netimicin, tobramycin. Isolates in genotype 3 are sensitive to all aminoglycosides.

\section{Genotypic distribution of chloramphenicol resistance genes}

The cat genes encode chloramphenicol acetyltransferase which detoxifies choramphenicol and is responsible for chloramphenicol resistance in bacteria [44]. Only two isolates harbored the cat1 gene and a 683 bp gene product was seen (Figure 5). These two isolates were also found to express the cat 2 gene and produced a $547 \mathrm{bp}$ gene product (Figure 6) while the primer for cat3 gene [38] didn't yield any amplicon (not shown). The $\mathrm{cml}$ and $f l o R$ genes confer resistance to chloramphenicol and florfenicol by efflux of the antibiotics [45]. The $c m l A$ gene was seen to be harbored in three isolates with an approximate length of 683 bp gene product (Figure 7) while the primer for $\mathrm{cmlB}$ gene [38] failed to detect any amplicon (not shown). The florfenicol resistance gene, floR was present in two isolates and gave 1213 bp gene product (Figure 8). One study has been documented that chloramphenicol resistance gene was found in six isolates while more (10 of the 14 multidrug-resistant) isolates were found to express the floR and cat 2 genes [13]. Two isolates harboured cat 3 and about $61 \%$ and 69\% isolates expressed $c m l A$ and $c m l B$ genes, respectively [13]. 
Citation: Nahar N, Rashid RB (2018) Phylogenetic Analysis of the Antibiotic Resistance Genes in Salmonella Species in silico. J Bioanal Biomed 10: 1-12. doi:10.4172/1948-593X.1000198

\begin{tabular}{|c|c|}
\hline Serial number & Isolate \\
\hline 1 & NC_021870 Salmonella bongori N268-08 \\
\hline 2 & NC_015761 Salmonella bongori NCTC 12419 \\
\hline 3 & NC_010067 Salmonella enterica subsp. arizonae serovar 62:z4, z23:-- \\
\hline 4 & NC_021818 Salmonella enterica subsp. enterica serovar Cubana str. CFSAN002050 \\
\hline 5 & NC_022991 Salmonella enterica subsp. enterica serovarAgona str. 24249 \\
\hline 6 & NC_011149 Salmonella enterica subsp. enterica serovar Agona str. SL483 \\
\hline 7 & NC_021844 Salmonella enterica subsp. enterica serovar Bareilly str. CFSAN000189 \\
\hline 8 & NC_022241 Salmonella enterica subsp. enterica serovar Bovismorbificans str. 3114 \\
\hline 9 & NC_006905 Salmonella enterica subsp. enterica serovar Choleraesuis str. SC-B67 \\
\hline 10 & NC_011205 Salmonella enterica subsp. enterica serovar Dublin str. CT_02021853 \\
\hline 11 & NC_011294 Salmonella enterica subsp. enterica serovar Enteritidis str. P125109 \\
\hline 12 & NC_011274 Salmonella enterica subsp. enterica serovar Gallinarum str. 287/91 \\
\hline 13 & NC_022221 Salmonella enterica subsp. enterica serovar Gallinarum/pullorum str. CDC1983-67 \\
\hline 14 & NC_016831 Salmonella enterica subsp. enterica serovar Gallinarum/pullorum str. RKS5078 \\
\hline 15 & NC_021810 Salmonella enterica subsp. enterica serovar Heidelberg str. 41578 \\
\hline 16 & NC_017623 Salmonella enterica subsp. enterica serovar Heidelberg str. B182 \\
\hline 17 & NC_021812 Salmonella enterica subsp. enterica serovar Heidelberg str. CFSAN002069 \\
\hline 18 & NC_011083 Salmonella enterica subsp. enterica serovar Heidelberg str. SL476 \\
\hline 19 & NC_020307 Salmonella enterica subsp. enterica serovar Javiana str. CFSAN001992 \\
\hline 20 & NC_011080 Salmonella enterica subsp. enterica serovar Newport str. SL254 \\
\hline 21 & NC_021902 Salmonella enterica subsp. enterica serovar Newport str. USMARC-S3124.1 \\
\hline 22 & NC_011147 Salmonella enterica subsp. enterica serovar Paratyphi A str. AKU_12601 \\
\hline 23 & NC_006511 Salmonella enterica subsp. enterica serovar Paratyphi A str. ATCC 9150 \\
\hline 24 & NC_010102 Salmonella enterica subsp. enterica serovar Paratyphi B str. SPB7 \\
\hline 25 & NC_012125 Salmonella enterica subsp. enterica serovar Paratyphi C strain RKS4594 \\
\hline 26 & NC_021984 Salmonella enterica subsp. enterica serovar Pullorum str. S06004 \\
\hline 27 & NC_011094 Salmonella enterica subsp. enterica serovar Schwarzengrund str. CVM19633 \\
\hline 28 & NC_022525 Salmonella enterica subsp. enterica serovar Thompson str. RM6836 \\
\hline 29 & NC_003198 Salmonella enterica subsp. enterica serovar Typhi \\
\hline 30 & NC_004631 Salmonella enterica subsp. enterica serovar Typhi Ty2 \\
\hline 31 & NC_016832 Salmonella enterica subsp. enterica serovar Typhi str. P-stx-12 \\
\hline 32 & NC_021176 Salmonella enterica subsp. enterica serovar Typhi str. Ty21a \\
\hline 33 & NC_022569 Salmonella enterica subsp. enterica serovar Typhimurium DT104 \\
\hline 34 & NC_003197 Salmonella enterica subsp. enterica serovar Typhimurium LT2 \\
\hline 35 & NC_021820 Salmonella enterica subsp. enterica serovar Typhimurium str. 08-1736 \\
\hline 36 & NC_016856 Salmonella enterica subsp. enterica serovar Typhimurium str. 14028S \\
\hline 37 & NC_017046 Salmonella enterica subsp. enterica serovar Typhimurium str. 798 \\
\hline 38 & NC_016854 Salmonella enterica subsp. enterica serovar Typhimurium str. D23580 \\
\hline 39 & NC_022544 Salmonella enterica subsp. enterica serovar Typhimurium str. DT2 \\
\hline 40 & NC_016810 Salmonella enterica subsp. enterica serovar Typhimurium str. SL1344 \\
\hline 41 & NC_016857 Salmonella enterica subsp. enterica serovar Typhimurium str. ST4/74 \\
\hline 42 & NC_016860 Salmonella enterica subsp. enterica serovar Typhimurium str. T000240 \\
\hline 43 & NC_021151 Salmonella enterica subsp. enterica serovar Typhimurium str. U288 \\
\hline 44 & NC_016863 Salmonella enterica subsp. enterica serovar Typhimurium str. UK-1 \\
\hline 45 & NC_021814 Salmonella enterica subsp. enterica serovar Typhimurium var. 5- str. CFSAN001921 \\
\hline
\end{tabular}

Table 1: Name of the isolates.

The $c m l A$ and $f l o R$ both genes were present in the same number in genotype 1 (11.11\%) (Figure 9). Genotype 2 contained four chloramphenicol resistance genes (except $\mathrm{cmlB}$ gene) and about $5.88 \%$ isolates present in genotype 2 expressed all four chloramphenicol resistance genes. Twenty-five percent isolates present in genotype 4 harboured cat 1 and cat 2 genes while genotype 5 contained only $\mathrm{cmlA}$ genes $(9.09 \%)$. Isolates in genotype 1 and 5 are likely to be resistant to chloramphenicol by enzyme detoxification rather than efflux while the reverse is true for genotype 2 and 4 . All isolates of genotype 3 will be sensitive to chloramphenicol while all isolates in genotype 3-5 will be sensitive to florfenicol [46].

\section{Genotypic distribution of fluoroquinolone resistance genes}

Mutations in $g y r A, g y r B$ regions of DNA gyrase and parC and parE regions of DNA topoisomerase IV have been responsible for fluoroquinolone resistance [47]. The gyrA gene was found in 43 positive isolates out of 45 isolates studied here and gave 251 bp gene products (Figure 10). Thirty isolates (66.67\%) were found to possess gyrB gene and produced $172 \mathrm{bp}$ gene products (Figure 11). Hence the mutations in the gyrA subunit are more likely to contribute to resistance when compared to $g y r B$. Thirty-one $(68.89 \%)$ isolates were found to express topoisomerase IV, parC gene with 262 bp gene 
Citation: Nahar N, Rashid RB (2018) Phylogenetic Analysis of the Antibiotic Resistance Genes in Salmonella Species in silico. J Bioanal Biomed 10: 1-12. doi:10.4172/1948-593X.1000198

\begin{tabular}{|c|c|c|c|}
\hline Gene & $\begin{array}{l}\text { Primer sequence } \\
\quad\left(5^{\prime}-3^{\prime}\right)\end{array}$ & $\begin{array}{l}\text { Amplicon size } \\
\text { bp }\end{array}$ & References \\
\hline $\operatorname{aad} A 1$ & $\begin{array}{l}\text { TTTGCTGGTTACGGTGAC } \\
\text { GCTCCATTGCCCAGTCG }\end{array}$ & 497 & {$[38]$} \\
\hline $\operatorname{aad} A 2$ & $\begin{array}{l}\text { GGTGCTAAGCGTCATTGAGC } \\
\text { GCTTCAAGGTTTCCCTCAGC }\end{array}$ & 470 & [38] \\
\hline aph (3')-Ila & $\begin{array}{l}\text { TCTGAAACATGGCAAAGGTAG } \\
\text { AGCCGTTTCTGTAATGAAGGA }\end{array}$ & 582 & {$[38]$} \\
\hline cat1 & $\begin{array}{l}\text { AACCAGACCGTTCAGCTGGAT } \\
\text { CCTGCCACTCATCGCAGTAC }\end{array}$ & 550 & [38] \\
\hline cat2 & $\begin{array}{l}\text { AACGGCATGATGAACCTGAA } \\
\text { ATCCCAATGGCATCGTAAAG }\end{array}$ & 547 & [38] \\
\hline $\mathrm{cmlA}$ & $\begin{array}{l}\text { GGCCTCGCTCTTACGTCATC } \\
\text { GCGACACCAATACCCACTAGC }\end{array}$ & 662 & [38] \\
\hline floR & $\begin{array}{l}\text { ATGACCACCACACGCCCCG } \\
\text { AGACGACTGGCGACTTCTCG }\end{array}$ & 1213 & [38] \\
\hline gyrA & $\begin{array}{l}\text { CGTTGGTGACGTAATCGG } \\
\text { CCGTACCGTCATAGTTAT }\end{array}$ & 251 & [31] \\
\hline gyrB & $\begin{array}{c}\text { GCGCTGTCCGAACTGTACCT } \\
\text { CGGTGATCAGCGTCGCCACTTCC }\end{array}$ & 172 & [31] \\
\hline parC & $\begin{array}{l}\text { CTATGCGATGTCAGAGCTGG } \\
\text { TAACAGCAGCTCGGCGTATT }\end{array}$ & 262 & [31] \\
\hline parE & $\begin{array}{l}\text { TCTCTTCCGATGAAGTGCTG } \\
\text { ATACGGTATAGCGGCGGTAG }\end{array}$ & 238 & [31] \\
\hline tet $A$ & $\begin{array}{l}\text { TTGGCATTCTGCATTCACTC } \\
\text { GTATAGCTTGCCGGAAGTCG }\end{array}$ & 494 & [38] \\
\hline tet $G$ & $\begin{array}{l}\text { GCTCGGTGGTATCTCTGCTC } \\
\text { CAAAGCCCCTTGCTTGTTAC }\end{array}$ & 550 & [38] \\
\hline sull & $\begin{array}{l}\text { TTTCCTGACCCTGCGCTCTAT } \\
\text { GTGCGGACGTAGTCAGCGCCA }\end{array}$ & 425 & [38] \\
\hline sullI & $\begin{array}{l}\text { CCTGTTTCGTCCGACACAGA } \\
\text { GAAGCGCAGCCGCAATTCAT }\end{array}$ & 435 & {$[38]$} \\
\hline sullII & $\begin{array}{l}\text { ATGAGCAAGATTTTTTGGAATCGTAA } \\
\text { CTAACCTAGGGCTTTGGATATTT }\end{array}$ & 792 & [38] \\
\hline
\end{tabular}

Table 2: Primers for antibiotic resistance genes detection.

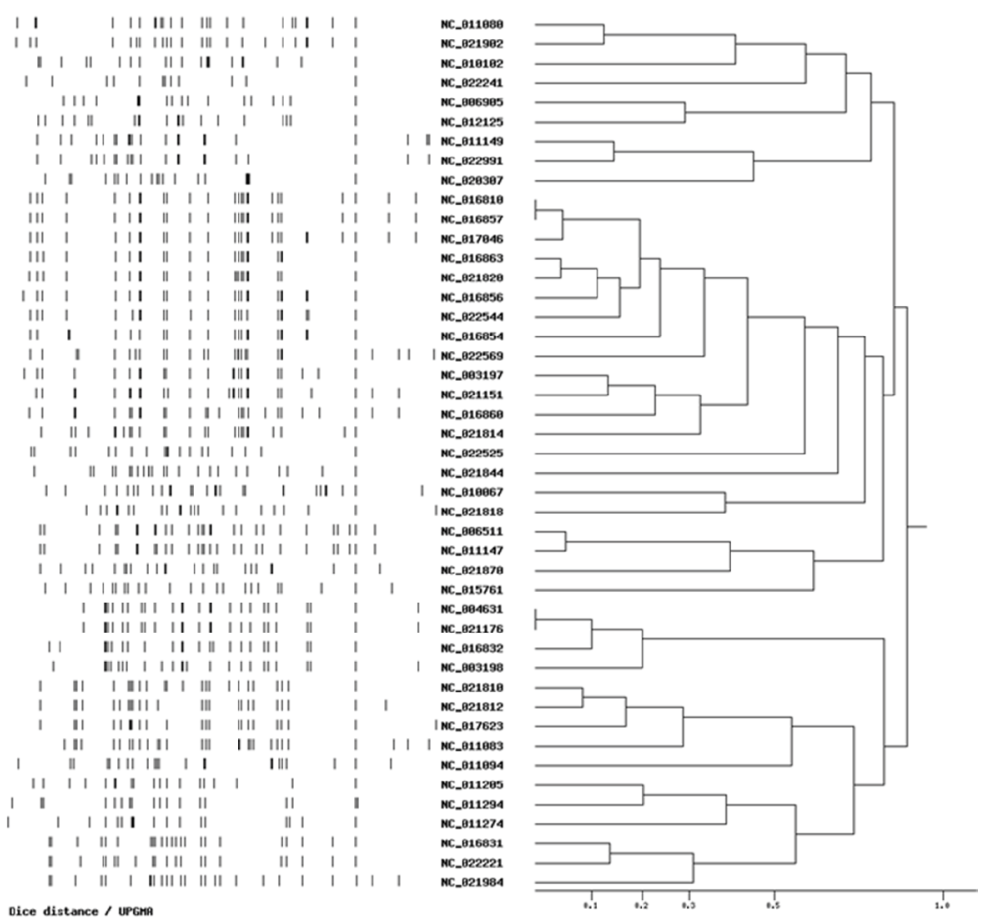

Figure 1: Phylogenetic diversity of Salmonella species identified by PFGE analysis. 


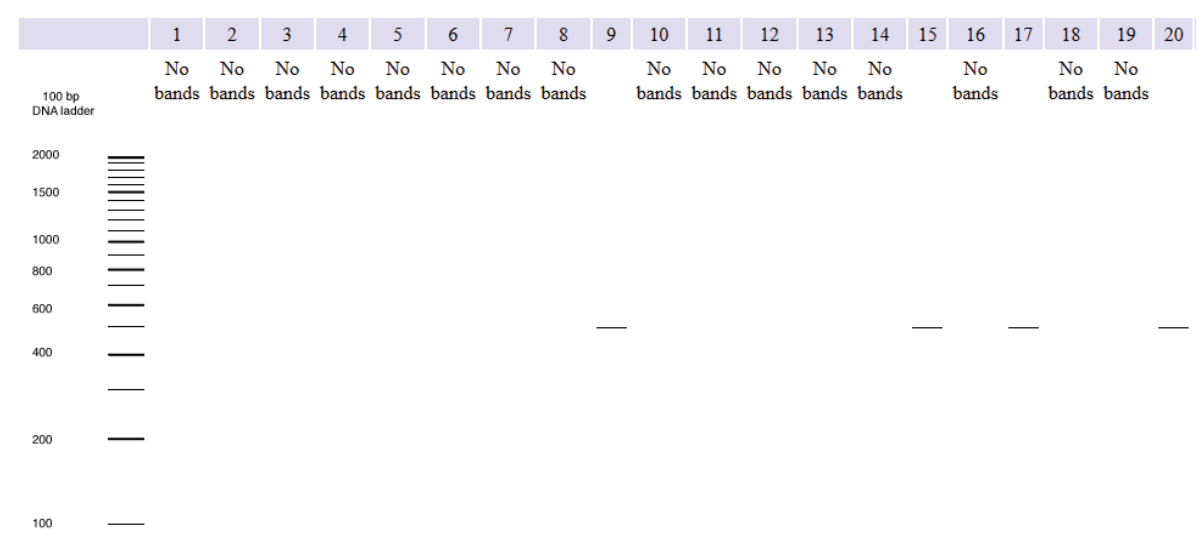

Figure 2: Detection of aadA1 gene in Salmonella isolates. Isolates harbouring the gene gives a $497 \mathrm{bp}$ amplicon.

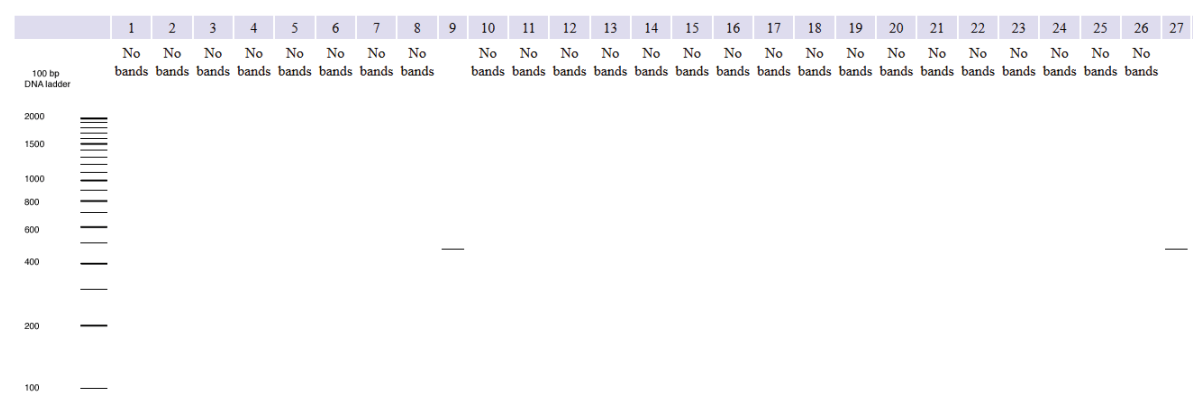

Figure 3: Detection of aadA2 gene in Salmonella isolates. Isolates harbouring the gene gives a $470 \mathrm{bp}$ amplicon.

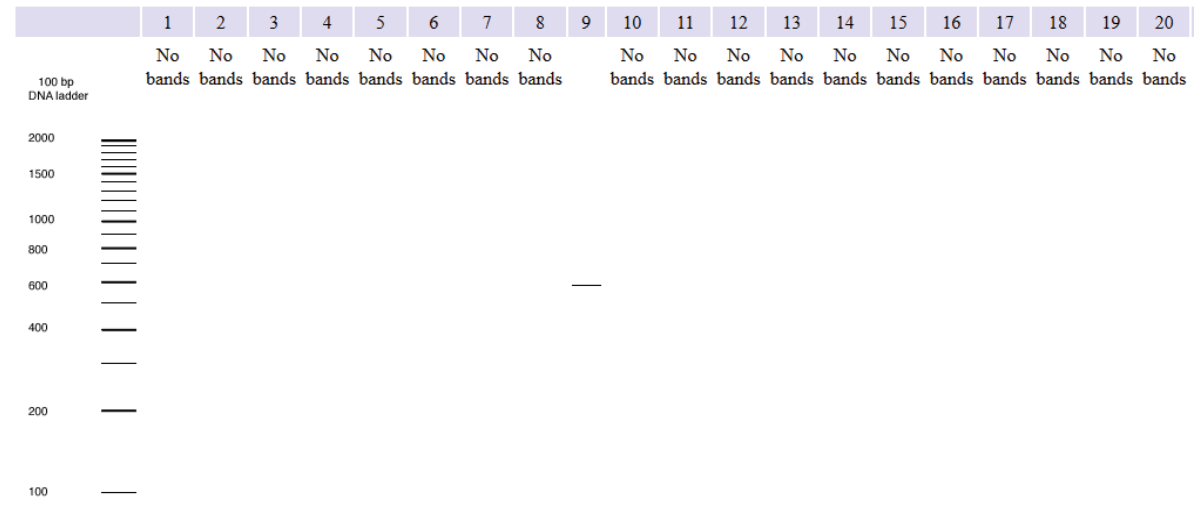

Figure 4: Detection of aph (3'):Ila gene in Salmonella isolates. Isolates harbouring the gene gives a $582 \mathrm{bp}$ amplicon.

product (Figure 12) while parE gene was present in $15.56 \%(\mathrm{n}=7)$ of the isolates with an approximate length of $238 \mathrm{bp}$ gene product (Figure 13). Our data suggests mutations in DNA gyrase are more likely the reason of resistance in comparison to DNA topoisomerase IV. Genotype 2 and 5 carried all four fluoroquinolone resistance genes (Figure 14). All the isolates present in genotype 5 carried $g y r A$ and $\operatorname{parC}$ genes (100\%) while about $90.91 \%$ and $54.55 \%$ isolates present in genotype 5 expressed gyrB and parE genes. All the isolates present in genotype 4 carried all resistance genes except parE. The gyrA was more prevalent in genotype $1(100 \%)$ while Genotype 3 harboured only gyrA gene (75\%). Because of the high prevalence of alteast one gene responsible for fluoroquinolone resistance through all genotypes, eradicating Salmonella with fluoroquinolone is unlikely to yield positive results. Fluoroquinolones are the most commonly used antibiotic in the poultry industry [47] where Salmonella is frequently isolated. Hence it is no surprise that the excessive use of fluoroquinolones have contributed to the widespread resistance.

\section{Genotypic distribution of tetracycline resistance genes}

The tet $A$ and tet $G$ both encode efflux proteins associated with pumping out tetracyclines from the cytosol to the extracellular environment [48]. Tetracycline resistance gene, tet $A$ was detected in 


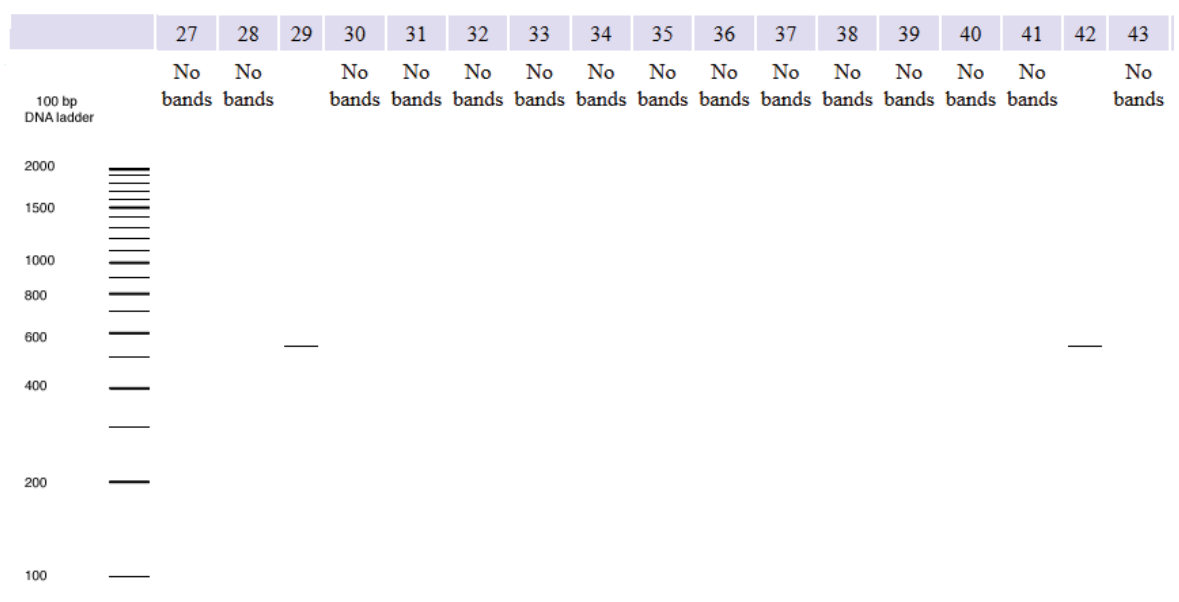

Figure 5: Detection of cat1 gene in Salmonella isolates. Isolates harbouring the gene gives a $550 \mathrm{bp}$ amplicon.

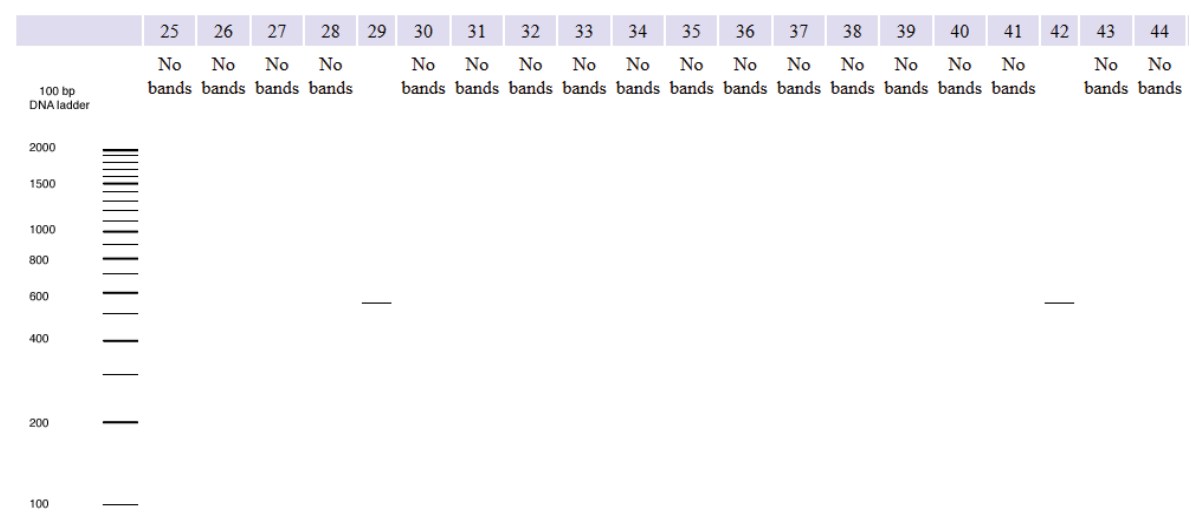

Figure 6: Detection of cat2 gene in Salmonella isolates. Isolates harbouring the gene gives a $547 \mathrm{bp}$ amplicon.

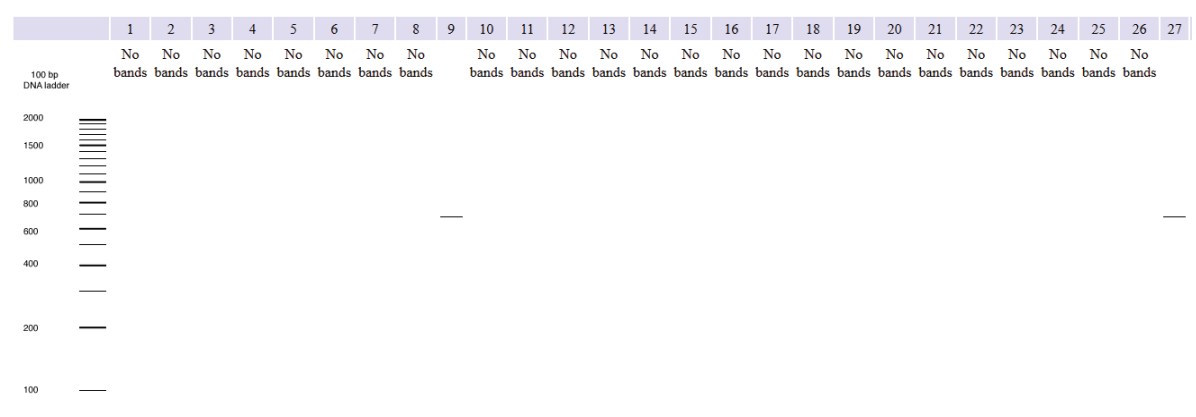

Figure 7: Detection of $\mathrm{cm} /$ gene in Salmonella isolates. Isolates harbouring the gene gives a $662 \mathrm{bp}$ amplicon.

$8.89 \%(\mathrm{n}=4)$ of the isolates with 494 bp gene product (Figure 15) while tet $G$ gene was found in only one isolate (Salmonella enterica subsp. enterica serovar Typhimurium DT104) with an approximate length of $550 \mathrm{bp}$ PCR product (Figure 16). Hence the tetA efflux protein is more common than tetG efflux protein. Resistance genes such as tet $M$, tet $O$, tet $S$ confer resistance by ribosomal protection whereas tet $X$ encodes proteins responsible for enzymatic alteration [48]. The primer for other tetracycline resistance genes [38] failed to give any amplicon product (not shown). The tetA gene was found in genotype 1, 2 and 5. Hence the isolates in other genotypes are unlikely to be tetracycline resistant because of tetA gene. About $11.11 \%$ and $18.18 \%$ isolates present in genotype 1 and 5 carried the tet $A$ genes. About $5.88 \%$ isolates present in genotype 2 expressed both tet $A$ and tet $G$ genes. Genotype 3 contained no tetracycline resistance genes and hence any isolate belonging to this genotype will be sensitive to tetracycline. Other than genotype 2 , isolates belonging to other genotypes are unlikely to resistant to tetracyline due to the efflux protein $t e t G$.

\section{Genotypic distribution of sulfonamide resistance genes}

Sulfonamide resistance gene, sulI was detected in 7 isolates (15.56\%) with 425 bp gene product (Figure 17) while 8 isolates (17.78\%) gave 435 bp PCR products for sulII gene (Figure 18). The sulIII gene was present 


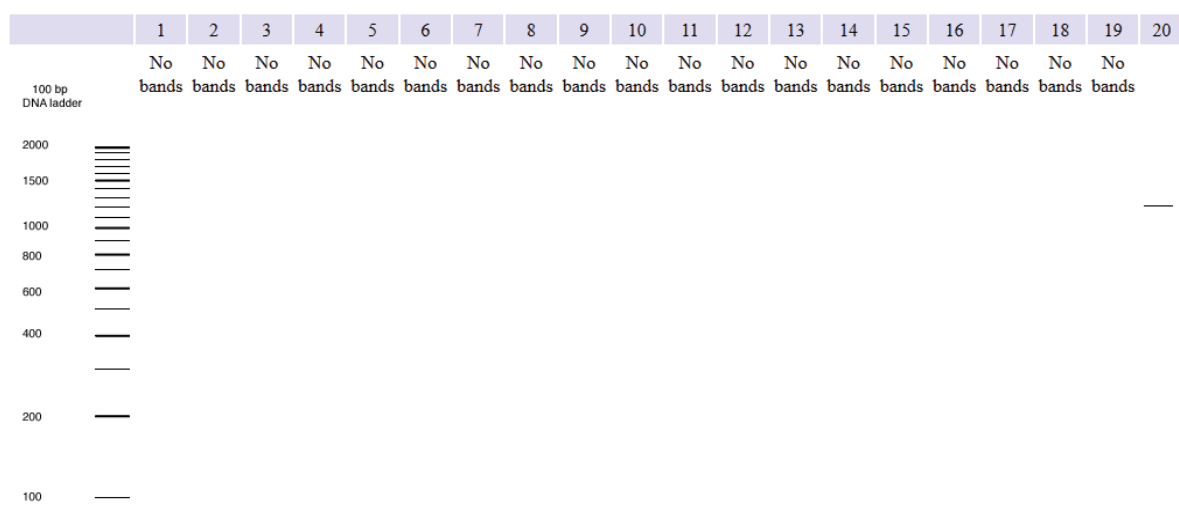

Figure 8: Detection of floR gene in Salmonella isolates. Isolates harbouring the gene gives a 1213 bp amplicon.

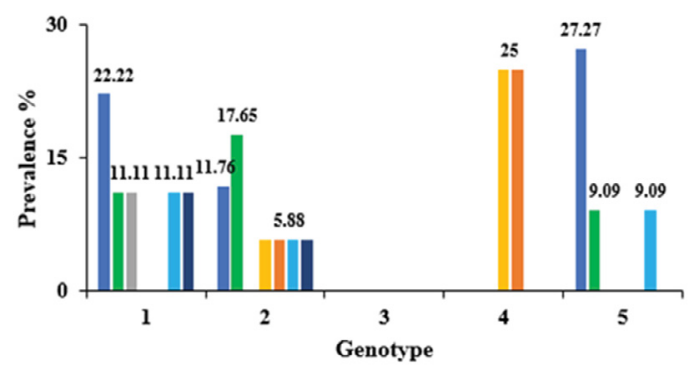

Figure 9: Genotypic distribution of aminoglycosides and chloramphenicol resistance genes. Genes encoding resistance proteins are as follows: aadA1: Aminoglycoside Adenyltransferase A1; aadA2: Aminoglycoside Adenyltransferase A2; aph (3'): Ila: Aminoglycoside O: Phosphotransferase Ila; cat1: Chloramphenicol Acetyltransferase 1; cat2: Chloramphenicol Acetyltransferase 2; cmIA: Non-Enzymatic Chloramphenicol Resistance A; floR: Florfenicol Resistance.

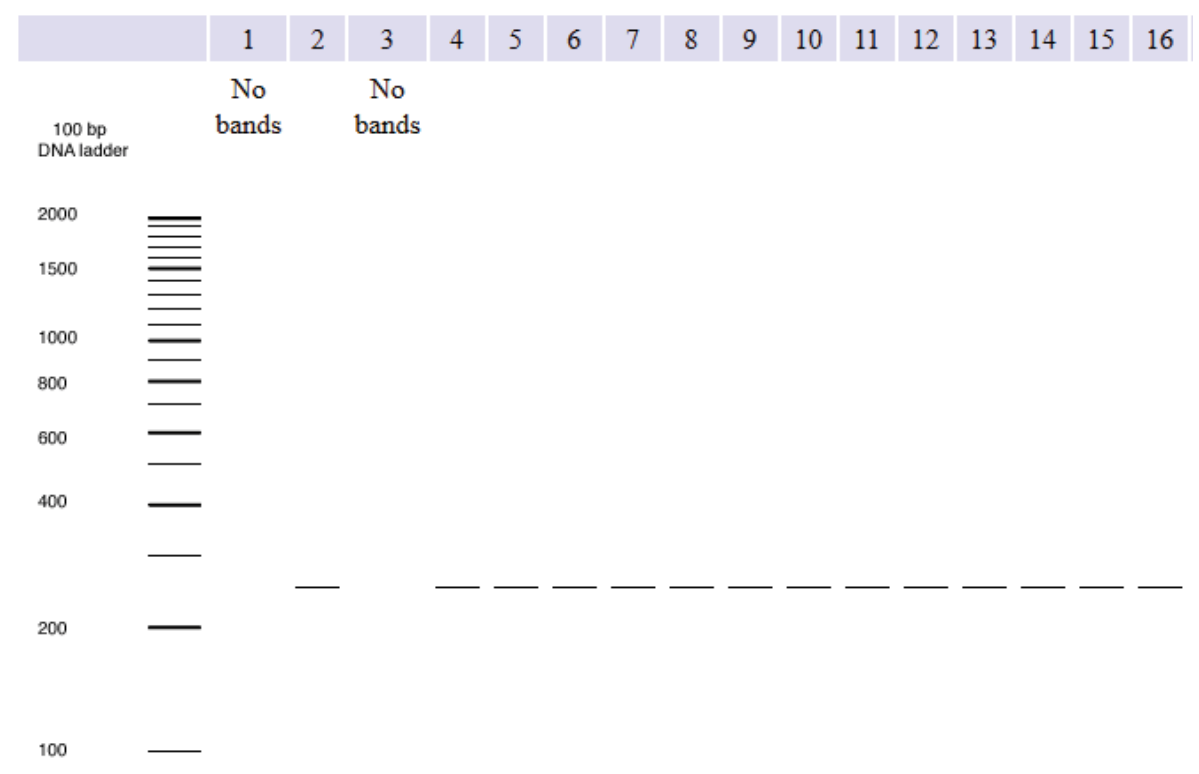

Figure 10: Detection of gyrA gene in Salmonella isolates. Isolates harbouring the gene gives a 251 bp amplicon.

in only three isolates and produced 792 bp gene products (Figure 19). Genotype 2 contained all five tetracycline and sulfonamide resistance genes (Figure 20). Genotype 1, 2 and 5 carried all three sulfonamide resistance genes. About $33.33 \%$ isolates present in genotype 1 harbored
sulI gene while $11.11 \%$ isolates in genotype 1 carried both sulII and sulIII genes. Twenty-five percent isolates in genotype 4 expressed sulII genes. Genotype 3 contained no sulfonamide resistance genes and hence any isolate from this genotype will be sensitive to sulfonamides. 


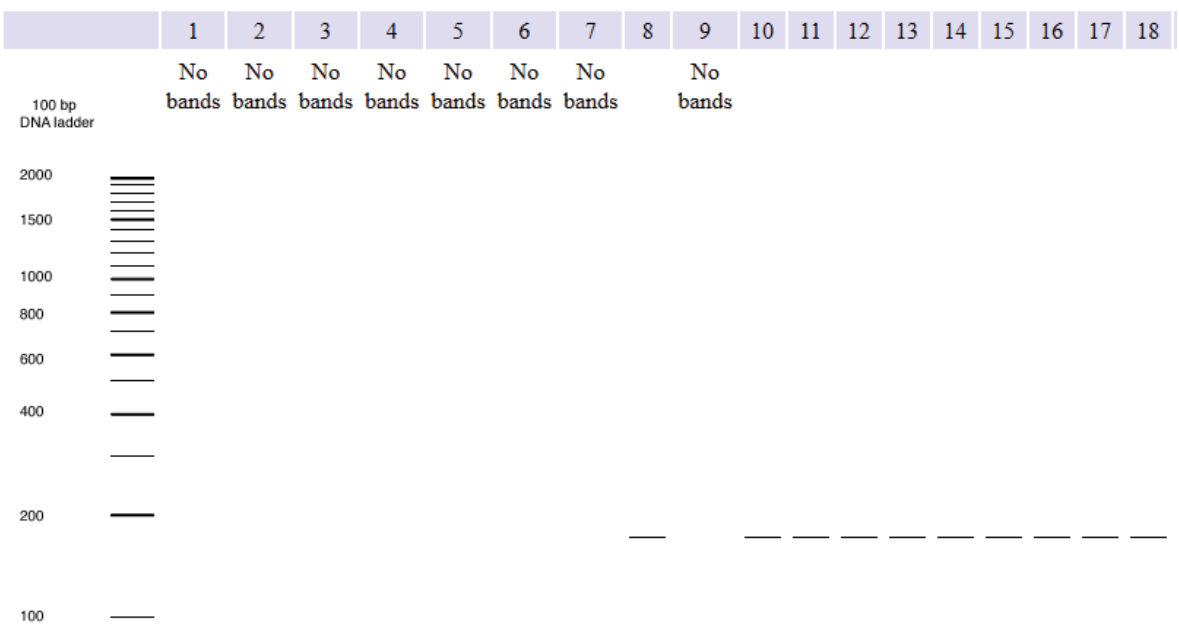

Figure 11: Detection of gyrB gene in Salmonella isolates. Isolates harbouring the gene gives a $172 \mathrm{bp}$ amplicon.

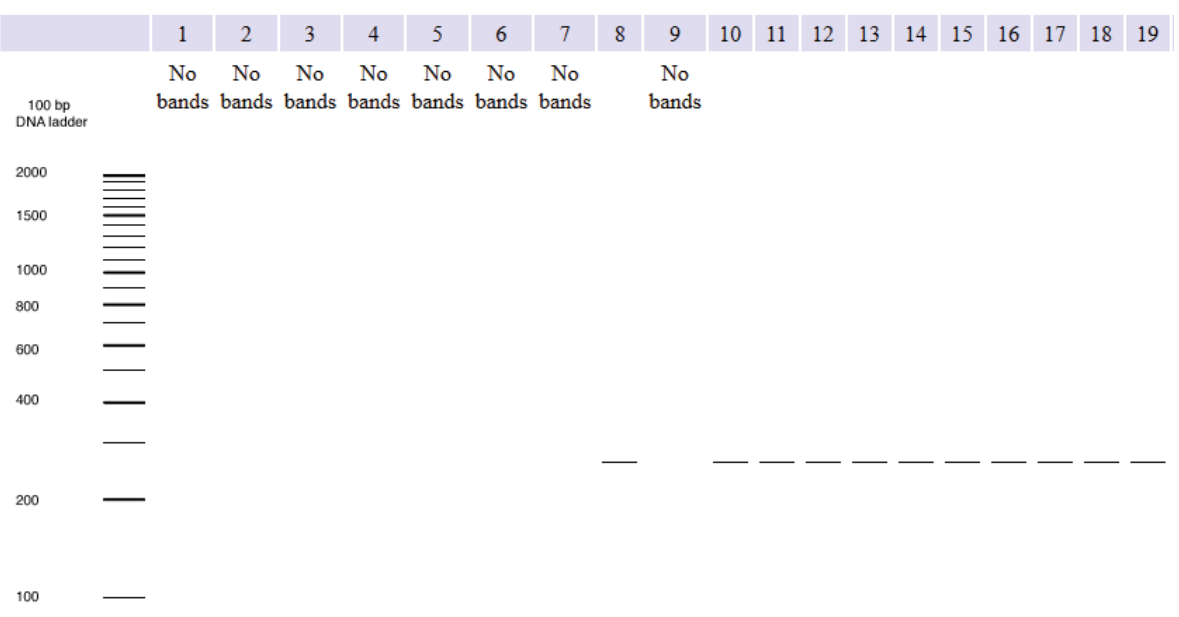

Figure 12: Detection of parC gene in Salmonella isolates. Isolates harbouring the gene gives a $262 \mathrm{bp}$ amplicon.

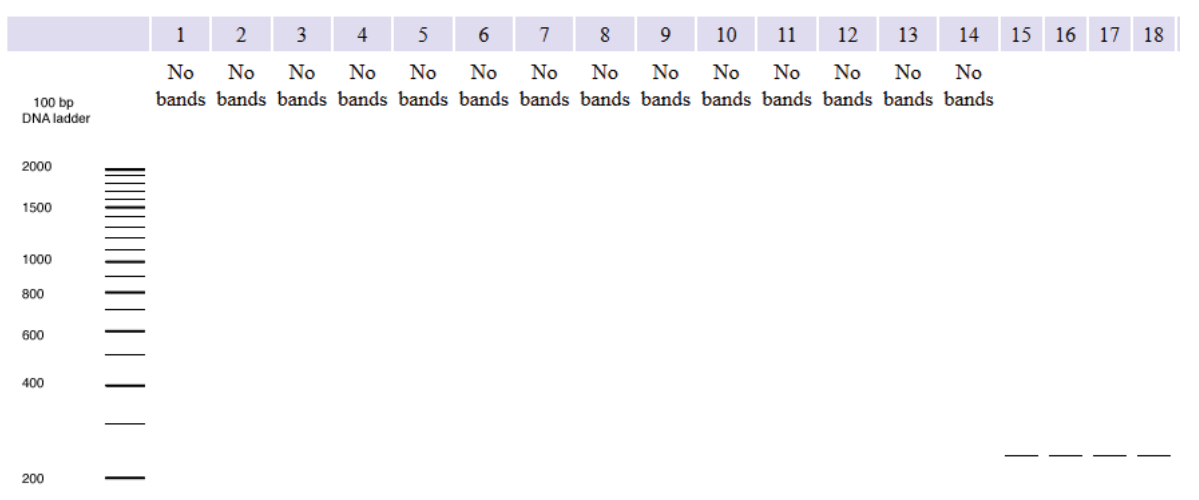

Figure 13: Detection of parE gene in Salmonella isolates. Isolates harbouring the gene gives a 238 bp amplicon. 


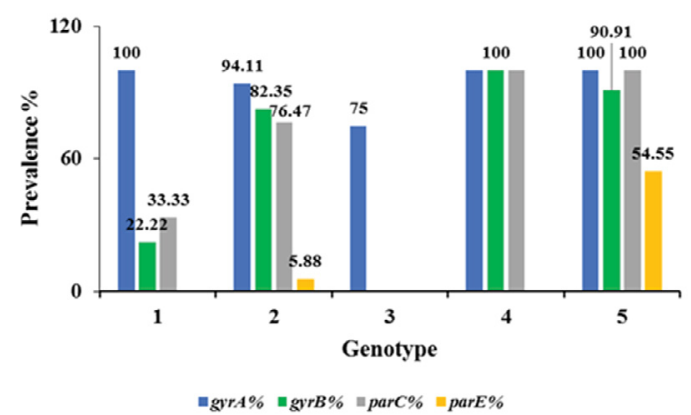

Figure 14: Genotypic distribution of fluoroquinolone resistance genes. Genes encoding resistance proteins are as follows: gyrA: gyrA Subunit of DNA Gyrase; gyrB: gyrB Subunit of DNA Gyrase; parC: parC Subunit of DNA Topoisomerase IV; pare: parE Subunit of DNA Topoisomerase IV.

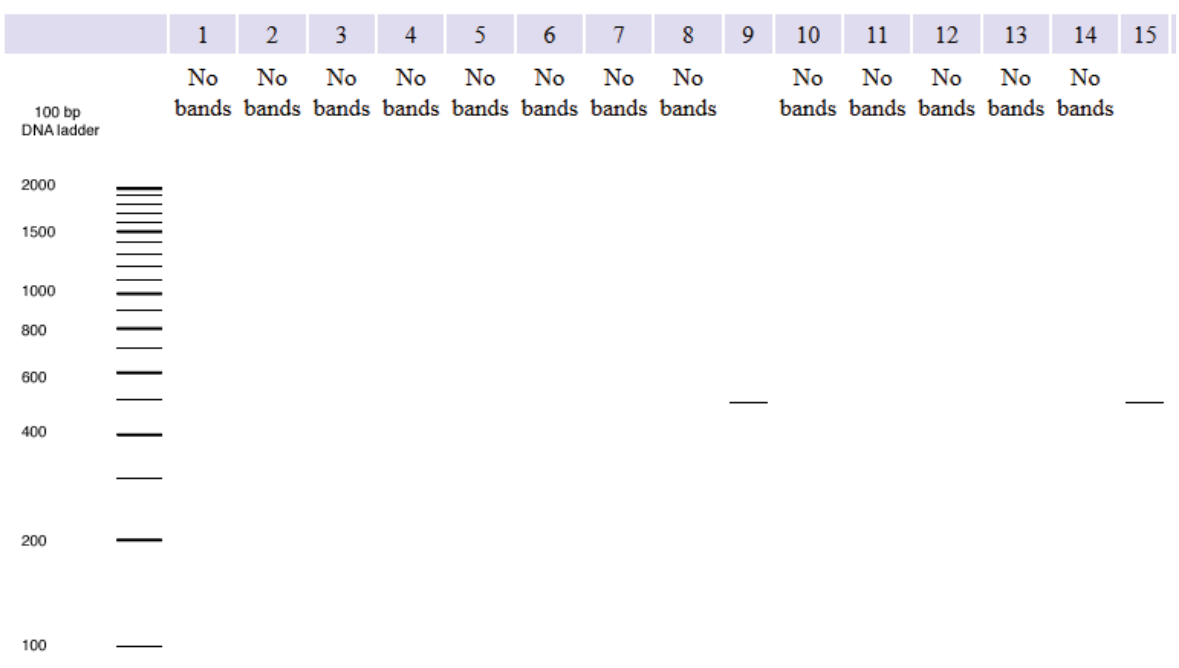

Figure 15: Detection of tetA in Salmonella isolates. Isolates harbouring the gene gives a 494 bp amplicon.

\begin{tabular}{|l|c|c|c|c|c|c|c|c|c|c|c|}
\hline 27 & 28 & 29 & 30 & 31 & 32 & 33 & 34 & 35 & 36 & 37 \\
\hline $\begin{array}{l}100 \mathrm{bp} \\
\text { DNA ladder }\end{array}$ & $\begin{array}{c}\text { No } \\
\text { bands bands bands bands bands bands }\end{array}$ & $\begin{array}{c}\text { No } \\
\text { bo }\end{array}$ & No & No & No & No & No & No \\
bands bands bands bands
\end{tabular}

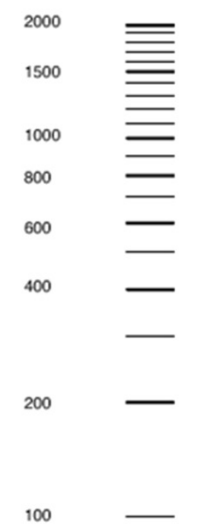

Figure 16: Detection of tetG in Salmonella isolates. Isolates harbouring the gene gives a 550 bp amplicon. 


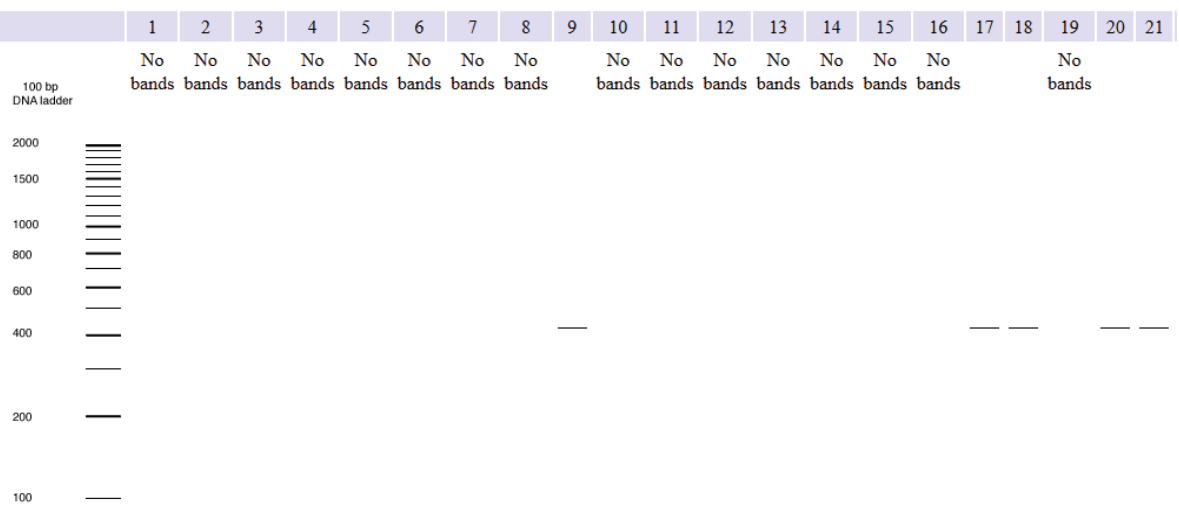

Figure 17: Detection of sull gene is Salmonella. Isolates harbouring the gene gives a 425 bp amplicon.

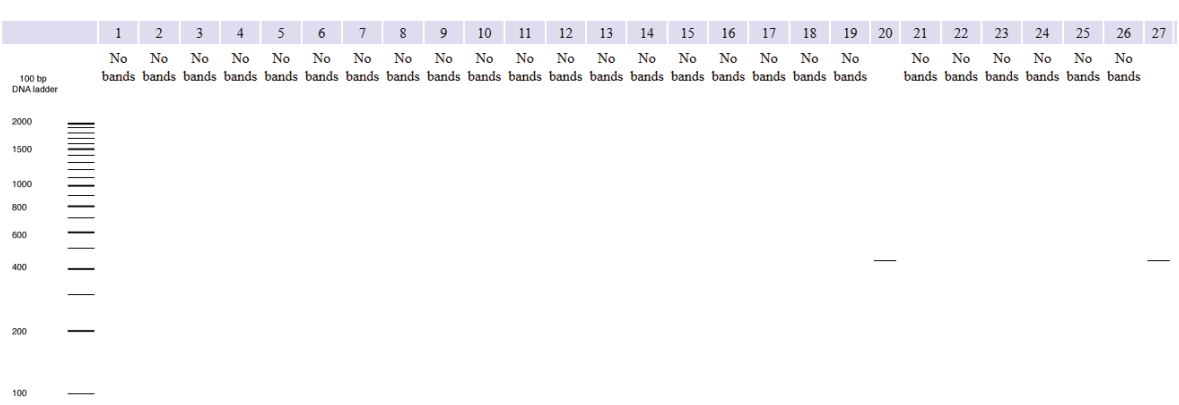

Figure 18: Detection of sulll gene is Salmonella. Isolates harbouring the gene gives a 435 bp amplicon.

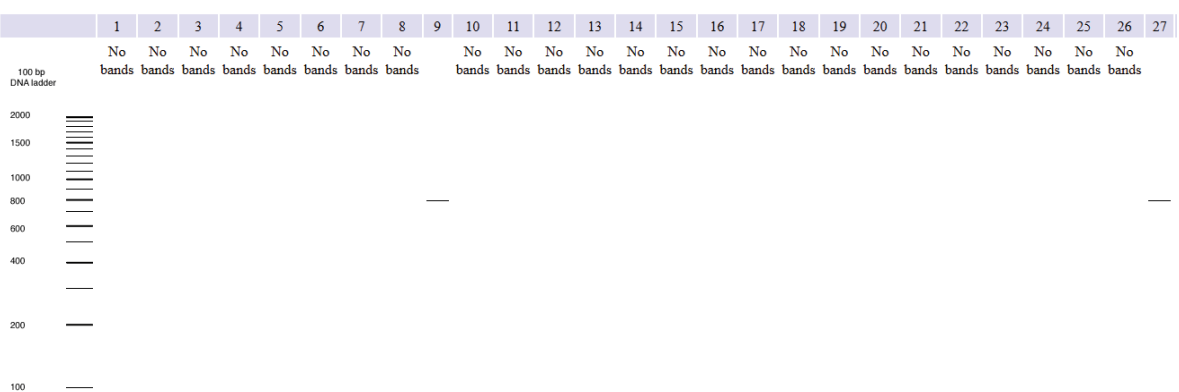

Figure 19: Detection of sullII gene is Salmonella. Isolates harbouring the gene gives a 792 bp amplicon.

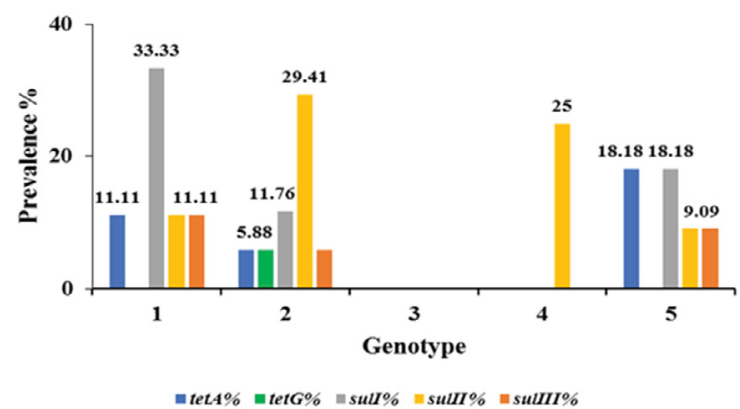

Figure 20: Genotypic distribution of tetracycline and sulfonamide resistance genes. Genes encoding resistance are as follows: tetA: Tetracycline Resistance Protein A; tetG: Tetracycline Resistance Protein G; sull: Sulfonamide Resistance Gene I; sulll: Sulfonamide Resistance Gene II; sullII: Sulfonamide Resistance Gene III. 


\section{Conclusion}

Our study used a computer aided approach to genotype and detects antibiotic resistance genes and assesses the how the prevalence of these genes varies across the genotypes. Our data suggests that the resistance profile of Salmonella as well as the mechanism of resistance varies across genotypes. Genotype 3 was sensitive to all antibiotics except the fluroquinolone family. The present study found that therapeutic value of fluoroquinolone antibiotic is limited since Salmonella strains since resistance genes were present across all genotypes. However, prevalence of resistance genes in genotype 3 was lower. Isolates in genotype 1 and 5 were resistant to chloramphenicol by enzyme detoxification rather than efflux while the reverse is true for genotype 2 and 4 . Mutations in $g y r A$, gyrB regions of DNA gyrase was more prevalent and hence has a greater contribution to fluoroquinolone resistance rather than mutations in parC and parE regions of DNA topoisomerase IV. Resistance due tetA efflux pump was more common than tetG pump and was only found in genotype 1,2 and 5. Tetracyline resistance due to ribosomal protection or enyme modification in Salmonella was not seen. Resistance due to sulfonamide was primarily due to sulII followed by sulI and sulIII. Treatment of Salmonella infection is going to have a better prognosis if tobramycin, gentamicin, kanamycin, neomycin, ribostamycin, butirosin, paromomycin are used instead of other aminoglycosides such as streptomycin and spectinomycin because resistance genes for these were not present. It can be concluded that treatment process of Salmonella infections is difficult since Salmonella strains harboured many antibiotic resistance genes. A collaborative scheme was to be setup to supervise the antibiotic administration in animals to prevent the antimicrobial resistance and also improved its therapeutic efficacy.

\section{References}

1. Salehi TZ, Mahzounieh M, Saeedzadeh A (2005) Detection of invA gene in isolated Salmonella from broilers by PCR method. Int J Poultry Sci 4: 557-559.

2. Antunes P, Réu C, Sousa JC, Peixe L, Pestana N (2003) Incidence of Salmonella from poultry products and their susceptibility to antimicrobial agents. Int J Food Microbiol 82: 97-103.

3. Shahada F, Chuma T, Tobata T, Okamoto K, Sueyoshi M, et al. (2006) Molecular epidemiology of antimicrobial resistance among Salmonella enterica serovar Infantis from poultry in Kagoshima, Japan. Int J Antimicrob Agents 28:302-307.

4. Nogrady N, Toth A, Kostyak A, Paszti J, Nagy B (2007) Emergence of multidrugresistant clones of Salmonella Infantis in broiler chickens and humans in Hungary. J Antimicrob Chemother 60: 645-648.

5. Schwarz S, Chaslus-Dancla E (2001) Use of antimicrobials in veterinary medicine and mechanisms of resistance. Vet Res 32: 201-225.

6. Bhowmick PP, Devegowda D, Ruwandeepika HA, Karunasagar I, Karunasagar I (2009) Presence of Salmonella. J Fish Dis 32: 801-805.

7. Smith SI, Fowora MA, Goodluck HA, Nwaokorie FO, Aboaba OO, et al. (2011) Molecular typing of Salmonella spp isolated from food handlers and animals in Nigeria. Int J Mol Epidemiol Genet 2: 73-77.

8. Jasovský D, Littmann J, Zorzet A, Cars O (2016) Antimicrobial resistance-a threat to the world's sustainable development. Ups J Med Sci 121: 159-164.

9. Van TT, Moutafis G, Istivan T, Tran LT, Coloe PJ (2007) Detection of Salmonella spp. in retail raw food samples from Vietnam and characterization of their antibiotic resistance. Appl Environ Microbiol 73: 6885-6890.

10. Kirk MD, Pires SM, Black RE, Caipo M, Crump JA, et al. (2015) World Health Organization estimates of the global and regional disease burden of 22 foodborne bacterial, protozoal and viral diseases, 2010: A data synthesis. PLoS Med 12: e1001921.

11. Crump JA, Luby SP, Mintz ED (2004) The global burden of typhoid fever. Bull World Health Organ 82: 346-353.
12. Fashae K, Ogunsola F, Aarestrup FM, Hendriksen RS (2010) Antimicrobia susceptibility and serovars of Salmonella from chickens and humans in Ibadan, Nigeria. J Infect Dev Ctries 4: 484-494.

13. Adesiji YO, Deekshit VK, Karunasagar I (2014) Antimicrobial-resistant genes associated with Salmonella spp. isolated from human, poultry, and seafood sources. Food Sci Nutr 2: 436-442.

14. Collignon P, Powers JH, Chiller TM, Aidara-Kane A, Aarestrup FM (2009) World Health Organization ranking of antimicrobials according to their importance in human medicine: A critical step for developing risk management strategies for the use of antimicrobials in food production animals. Clin Infect Dis 49: 132-141.

15. Akinyemi OK, Smith SI, Oyefolu AO, Fasure KA, Coker AO (2006) Trends of multiple drug resistance in Salmonella enterica serovar typhi in Lagos, Nigeria. East Cent Afr J Surg 12: 83-88.

16. Piddock LJ (2002) Fluoroquinolone resistance in Salmonella serovars isolated from humans and food animals. FEMS Microbiol Rev 26: 3-16.

17. Randall LP, Coldham NG, Woodward MJ (2005) Detection of mutations in Salmonella enterica gyrA, gyrB, parC and parE genes by denaturing high performance liquid chromatography (DHPLC) using standard HPLC instrumentation. J Antimicrob Chemother 56: 619-623.

18. Ling JM, Chan EW, Lam AW, Cheng AF (2003) Mutations in topoisomerase genes of fluoroquinolone-resistant salmonellae in Hong Kong. Antimicrob Agents Chemother 47: 3567-3573.

19. Eaves DJ, Liebana E, Woodward MJ, Piddock LJ (2002) Detection of gyrA mutations in quinolone-resistant Salmonella enterica by denaturing highperformance liquid chromatography. J Clin Microbiol 40: 4121-4125.

20. Eaves DJ, Randall L, Gray DT (2004) Effect of mutations within the QRDR of gyrA, gyrB, parC or parE in quinolone-resistant $\mathrm{S}$. enterica from humans and animals. Antimicrob Agents Chemother 48: 4012-4015.

21. Cannon M, Harford S, Davies JA (1990) A comparative study on the inhibitory actions of chloramphenicol, thiamphenicol and some fluorinated derivatives. J Antimicrob Chemother 26: 307-317.

22. Dorman CJ, Foster TJ (1982) Nonenzymatic chloramphenicol resistance determinants specified by plasmids R26 and R55-1 in Escherichia coli K-12 do not confer high-level resistance to fluorinated analogs. Antimicrob Agents Chemother 22: 912-914.

23. Nogrady N, Gado I, Fekete PZ, Paszti J (2005) Chloramphenicol resistance genes in Salmonella enterica subsp. enterica serovar Typhimurium isolated from human and animal sources in Hungary. Vet Med-Czech 50: 164-170.

24. Jafari RA, Ghorbanpour, Jaideri M (2007) An investigation in Salmonella status in backyard chicken in Iran. Int J Poul Sci 6: 227-229.

25. Mirzaie S, Hassanzadeh M, Ashrafi I (2010) Identification and characterization of Salmonella isolates from captured house sparrows. Turk J Vet Anim Sci 34 181- 186.

26. Morshed R, Peighambari SM (2010) Drug resistance, plasmid profile and random amplified polymorphic DNA analysis of Iranian isolates of Salmonella enteritidis. New Microbiol 3: 47-56.

27. Abbasoglu D, Akcelik M (2011) Phenotypic and genetic characterization of multidrug-resistant Salmonella infantis strains isolated from broiler chicken meats in Turkey. Biologia 66: 406-410.

28. Tajbakhsh M, Hendriksen RS, Nochi Z, Zali M, Aarestrup FM, et al. (2012) Antimicrobial resistance in Salmonella spp. recovered from patients admitted to six different hospitals in Tehran, Iran from 2007 to 2008. Folia Microbiol 57: 91-97.

29. Fonseca EL, Mykytczuk OL, Asensi MD, Reis EMF, Ferraz LR, et al. (2006) Clonality and antimicrobial resistance gene profiles of multidrug-resistant Salmonella enterica serovar Infantis isolates from four public hospitals in Rio de Janeiro, Brazil. J Clin Microbiol 44: 2767-2772.

30. Walker RA1, Lindsay E, Woodward MJ, Ward LR, Threlfall EJ (2001) Variation in clonality and antibiotic-resistance genes among multiresistant Salmonella enterica serotype typhimurium phage-type U302 (MR U302) from humans, animals, and foods. Microb Drug Resist 7: 13-21.

31. Randall LP, Cooles SW, Osborn MK, Piddock, LJV, Woodward MJ (2004) Antibiotic resistance genes, integrons and multiple antibiotic resistance in thirty-five serotypes of Salmonella enterica isolated from humans and animals in the UK. J Antimicrob Chemother 3: 208- 216. 
Citation: Nahar N, Rashid RB (2018) Phylogenetic Analysis of the Antibiotic Resistance Genes in Salmonella Species in silico. J Bioanal Biomed 10: 1-12. doi:10.4172/1948-593X.1000198

32. Enne VI, Livermore DM, Stephens P, Hall LMC (2001) Persistence of sulfonamide resistance in Escherichia coli in the UK despite national prescribing restriction. Lancet 357: 1325-1328.

33. Sköld O1 (2000) Sulfonamide resistance: Mechanisms and trends. Drug Resist Updat 3: $155-160$.

34. Perreten V, Boerlin P (2003) A new sulfonamide resistance gene (sul3) in Escherichia coli is widespread in the pig population of Switzerland. Antimicrob Agents Chemother 47: 1169-1172.

35. Frye JG, Jackson CR (2013) Genetic mechanisms of antimicrobial resistance identified in Salmonella enterica, Escherichia coli and Enteroccocus spp. isolated from U.S. food animals. Front Microbiol 4: 135.

36. Shaw KJ, Rather PN, Hare RS, Miller GH (1993) Molecular genetics of aminoglycoside resistance genes and familial relationships of the aminoglycoside-modifying enzymes. Microbiol Rev 57: 138-163.

37. Ramirez MS, Tolmasky ME (2010) Aminoglycoside modifying enzymes. Drug Resist Update 13: 151-171.

38. Ma M, Wang H, Yu Y, Zhang D, Liu S (2007) Detection of antimicrobial resistance genes of pathogenic Salmonella from swine with DNA microarray. J Vet Diagn Invest 19: 161-167.

39. San Millán RM, Martínez-Ballesteros I, Rementeria A, Garaizar J, Bikandi J (2013) Online exercise for the design and simulation of PCR and PCR-RFLP experiments. BMC Res Notes 6: 513.

40. Bikandi J, San Millán R, Rementeria A, Garaizar J (2004) In silico analysis of complete bacterial genomes: PCR, AFLP-PCR and endonuclease restriction. Bioinformatics. 20: 798-799.
41. Jones LA, Mclver CJ, Kim MJ, Rawlinson WD, White PA (2005) The aadB gene cassette is associated with blaSHV genes in Klebsiella species producing extended-spectrum $\beta$-lactamases. Antimicrob Agents Chemother 49: 794-797.

42. Schwarz S, Gregory PD, Werckenthin C, Curnock S, Dyke KGH (1996) A nove plasmid from Staphylococcus epidermidis specifying resistance to kanamycin, neomycin and tetracycline. J Med Microbiol 45: 57-63.

43. Pournaras S, Slavakis A, Polyzou A, Sofianou D, Maniatis AN, et al. (2001) Nosocomial spread of an unusual methicillin-resistant Staphylococcus aureus clone that is sensitive to all non- $\beta$-lactam antibiotics, including tobramycin. J Clin Microbiol 39: 779-781.

44. Shaw WV, Packman LC, Burleigh BD, Dell A, Morris HR, et al. (1979) Primary structure of a chloramphenicol acetyltransferase specified by $\mathrm{R}$ plasmids. Nature 282: 870-872.

45. Schwarz S1, Kehrenberg C, Doublet B, Cloeckaert A (2004) Molecular basis of bacterial resistance to chloramphenicol and florfenicol. FEMS Microbiol Rev 28: 519-542.

46. González I, Georgiou M, Alcaide F, Balas D, Liñares J, et al. (1998) Fluoroquinolone resistance mutations in the parC, parE, and gyrA genes of clinical isolates of viridans group streptococci. Antimicrob Agents Chemother 42: $2792-2798$.

47. Gouvêa R, dos Santos FF, de Aquino MHC (2015) Fluoroquinolones in industrial poultry production, bacterial resistance and food residues: A review. Rev Bras Ciênc Avíc 17: 1-10.

48. Roberts MC (2011) Environmental macrolide-lincosamide-streptogramin and tetracycline resistant bacteria. Front Microbiol 2: 40 . 